Acta Universitatis Wratislaviensis No 3798

PRAWO CCCXXIII

Wrocław 2017

DOI: $10.19195 / 0524-4544.323 .22$

\author{
VIKTORIYA MALYGA \\ Ivan Franko National University of Lviv \\ e-mail: triadama@gmail.com
}

\title{
Implementation of the State Regulatory Policy in Ukraine
}

The concept "state regulatory policy" (hereinafter referred to as "SRP") appeared in our legislation not long time ago. Its content has been formed and changed since 2000, with the consideration of changes in economic sphere. State regulatory policy represents only one of the directions of the state policy, the purpose of which is to build perfect economic and administrative relations at the expense of strict limitations of the interference of state bodies in the activities of economic entities.

The concept of state regulatory policy was first established in the President's of Ukraine Decree of January 22, 2000 "On the introduction of a unified state regulatory policy in the sphere of entrepreneurship"1. State regulatory policy in the sphere of economic activity is defined as one of the directions of the state policy aimed at improving the legal regulation of economic relations, as well as administrative relations between the regulatory bodies or other bodies of state power and economic entities, preventing the adoption of economically unfeasible and ineffective regulatory acts, reduction of state interference in the activities of economic entities, elimination of obstacles to the development of economic activities carried out within the limits and in the order and manner established by the Constitution ${ }^{2}$ and laws of Ukraine. The very existence of such a concept tells

1 Про запровадження єдиної державної регуляторної політики в сфері підприємництва: Указ Президента України № 89/2000 від 22.01.2000 р. // Офіційний вісник України. — 2000. — № 4. - Ст. 107 (On the Introduction of the Common State Regulatory Policy in the Sphere of Entrepreneurship: The Decree of the President of Ukraine of 22 January 2000 No 89/2000 // Official Journal of Ukraine. - 2000. - No 4. - P. 107)

2 Конституція України від 28.06.1996 р. № 254к/96-ВР // Відомості Верховної Ради України. - 1996. - № 30. - Ст. 141 (Constitution of Ukraine of 28 June 1996 No 254к/96-BP / The Official Bulletin of the Verkhovna Rada of Ukraine. — 1996. — No 30. — P. 141). 
about the possibility of regulating relations not only by measures of state influence, but also by means of market mechanisms. It is, rather, a question of clearly establishing the limits of state intervention in economic processes by identifying those areas that can not function effectively without state regulation. At the same time, the basis of the SRP is the concept of "regulatory act", that is a legal act, which, in whole or in part, is aimed at the regulation of economic and administrative relations (between state authorities and economic entities). It should be noted the presence of targeted regulatory provision of SRP, the evidence of which is the adoption of a number of legal acts at various levels of government. It is important to note that most of them use the concept of "unified state regulatory policy", the definition of which is absent. Unity means the existence of common goals and principles of the implementation of state influence in such a form. The main functions for the implementation of regulatory policy are now entrusted to the State Regulatory Service of Ukraine ${ }^{3}$.

State regulation of the economy is an obligatory element of the structure of modern society. It is the state that ensures, due to certain measures and instruments, the effective functioning of the economy. One of the most important areas of this regulation is the state regulatory policy, which has emerged as an objective prerequisite for the formation of the economic order. Art. 5 of the Commercial Code of Ukraine 4 states that "the legal economic order in Ukraine is formed on the basis of the optimal combination of market self-regulation of economic relations between economic entities and state regulation of macroeconomic processes", so the formula of such symbiosis is the most important from the point of view of forming the foundations of a mixed economy in our state. At the same time, the regulatory policy itself is a highly complex, multidimensional phenomenon that has its own forms of implementation.

Such a policy is characterized by certain features:

1) it is one of the directions of state economic policy;

2) the only purpose of regulation is to establish maximum effectiveness of legal acts in the sphere of management;

3) achievement of this goal is possible due to the improvement of legal regulation; establishing the optimal limits of government intervention in the activities of business entities; elimination of obstacles to the development of economic activity;

3 Положення про Державну регуляторну службу України: Затв-но Постановою Кабінету Міністрів України № 724 від 24 грудня 2014 р. // Офіційний вісник України. — 2015. — № 4. - Ст. 68 (Regulation on The State Regulatory Service of Ukraine: Approved by The Resolution of the Cabinet of Ministers of Ukraine of 24 December 2014 No 724 // Official Journal of Ukraine. 2015. - No 4. - P. 68).

4 Господарський кодекс України № 436-IV від 16.01.2003 р. // Відомості Верховної Ради України. - 2003. - № 18. - Ст. 144 (Commercial Code of Ukraine of 16 January 2003 No 436IV / The Official Bulletin of the Verkhovna Rada of Ukraine. - 2003. - No 18. - P. 144). 
4) existence of a hierarchical system of state bodies involved in the implementation of this policy;

5) the order and methods of such state influence are clearly established by the current legislation.

The legal definition of SRP contains (albeit indirectly) an indication of those principles on which it is based. In particular, it is about the principles of expediency and effectiveness of regulatory acts, the principle of reducing government intervention in the activities of business entities.

The very existence of such a concept tells about the possibility of regulating relations not only and not so much by measures of state influence. It is, rather, a question of clearly establishing the limits of state intervention in economic processes by identifying those areas that cannot function effectively without state regulation.

The state has defined and fixed the special character of the SRP in the following way:

1) the object, to which the state impact was directed, was clearly fixed;

2) impossibility of solving the problems of management with the help of market mechanisms or existing regulatory acts was justified;

3 ) the procedure for determining (defining) the necessity for the government intervention in the sphere of entrepreneurial risk is gradually defined;

4) the effectiveness of the regulatory act comes first, and attempts are made to establish its main indicators beforehand, that is, before it enters into force ${ }^{5}$.

Regulatory policy could become a real stabilizing factor through the proper settlement of certain economic and administrative relations through the adoption of regulatory acts. It is precisely their quantity and quality that the state of the entrepreneurial environment depends on, which, in turn, directly affects the economic system in general.

Regulatory bodies have special powers for preparing, adopting, monitoring and revising regulatory acts. All these procedures are aimed, first of all, at establishing an appropriate system of state regulation and control in the sphere of management.

The stabilizing influence of the state regulatory policy is based on the implementation of the mechanisms of action of its main principles, among which it should be called expediency, adequacy, efficiency, balance, predictability, transparency and consideration of public opinion.

It is these actual parameters that allow creating a certain algorithm for the formation and functioning of the state regulatory policy, which may look like as

5 Про засади державної регуляторної політики у сфері господарської діяльності: Закон України № 1160-IV від 11.09.2003 р. // Відомості Верховної Ради України. — 2003. — № 9. - Ст. 79 (On the Principals of State Regulatory Policy in the Sphere of Economic Activity: The Law of Ukraine of 11 September 2003 No 1160-IV // The Official Bulletin of the Verkhovna Rada of Ukraine. - 2003. - No 9. - P. 79). 
follows: a unified approach to the preparation of regulatory acts allows to create a consistent, harmonious system of regulatory acts that produce the appropriate regulatory influence on the relevant legal relationship. At the same time, the process of preparation of regulatory acts is accompanied by the active participation of individual citizens and their groups, organized in a certain way, as well as other subjects of public life (through the promulgation of draft regulatory acts, public discussion, the consideration of specific proposals) for the maintenance of such acts and indirectly for the establishment of the limit of state regulation of certain processes in the sphere of management. At the same time, all regulatory acts appear in strict accordance with predetermined and publicly announced plans that can be transformed in the light of public opinion. The mechanism continues to operate through systematic monitoring of the effectiveness of regulatory acts (basic, repeated and periodic). In addition, even at this stage it is possible to adjust certain flaws of specific regulatory acts that were discovered during the use, which is why there is a procedure for revision of these acts. It should be noted that such an opportunity cannot negatively affect the state stability, since inadequate state regulation in the economic sphere destroys the basic principles of interaction between the state (in the face of its relevant bodies) and civil society that is yet being formed in Ukraine.

A kind of guarantee of state stability of regulatory influence may be the systematic nature of the regulatory policy, which is ensured by preventing the adoption of regulatory acts that are inconsistent, do not match or duplicate existing acts.

From the point of view of sustainability of state foundations, it is important to involve the wider public in forming regulatory influence and to take into account their comments and proposals to specific regulatory acts.

An integrated approach to eliminating obstacles on a way to ensuring state stability can be established taking into consideration the most important principles of the state regulatory policy, in the ideal form it allows to establish the boundaries of state regulation in the sphere of management.

The presence of targeted regulatory provision of SRP, evidence of which is the adoption of a number of legal acts at various levels of government should be noted. However, unity means the existence of common goals and principles for the realization of state influence in this form.

The adoption of a regulatory act is caused by setting of expected results. This process itself is carried out using the method of analysis of benefits and costs in a simple (list of expected positive and negative factors) or complex (using a variety of economic models) form. At the same time, in practice, in most cases, subjects choose a simple form, which does not require a lot of time and efforts.

Meanwhile, regulatory policy did not become the necessary instrument of state influence on the economy in Ukraine. Illustration of this statement may be the lack of a clear concept of the implementation of the state regulatory policy, according to which changes in legislation on economic activities can be made 
only in view of their effectiveness. It should be noted that this indicator should be determined not only in relation to the state itself, but also in view of the diverse interests of entrepreneurs, since in the case of giving priority to state needs, the risk of loss of entrepreneurship (entrepreneurial initiative) becomes especially actual. Basing on the above-stated, regulatory policy should become the most important regulator of economic processes in Ukraine with taking into account the following factors:

1) any changes in the economic sphere must take place within the framework of a general concept, formed and approved in advance, in accordance with the procedure established by law. This eliminates the possibility for state bodies to implement inconsistent (uncoordinated) measures of influence on economic activity;

2) there is a need for a state-wide level of discussion of the regulatory acts adoption, since the clear clarification of the ultimate goal of the adoption of any normative legal act will enable the formation of an effective (not only for the state but also for all entrepreneurs) economic (internally agreed) legislation. The final result of the economic reforms being implemented in Ukraine largely depends on how balanced is the position of society on adequate formation and implementation of the state regulatory policy, taking into account the determining influence of the effectiveness of such regulation.

\title{
Implementation of the State Regulatory Policy in Ukraine
}

\author{
Summary
}

The article considers the peculiarities of the concept and implementation of the state regulatory policy in Ukraine. The content of the main features of such a policy has been analyzed, its legal nature has been established and the most important problems of introduction of regulatory influence are revealed.

Keywords: state regulatory policy, regulatory body, regulatory act, subject to influence, sphere. 